Review Article

\title{
Postdramatic review of the einstein on the beach / train scene by Robert Wilson
}

\author{
Șahin Turan ${ }^{1}$
}

Istanbul Aydin University, Master Program at Theatre Directing, Turkey

\section{Article Info}

Received: 24 April 2020

Revised: 08 June 2020

Accepted: 12 June 2020

Available online: 15 June 2020

Keywords:

Dramatic

Postdramatic

Einstein, Robert Wilson

2717-8870 / (C) 2020 The Authors. Published by Young Wise Pub. Ltd. This is an open access article under the CC BY-NC-ND license
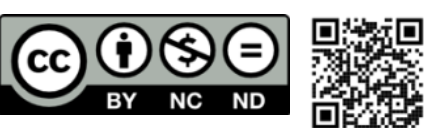

\begin{abstract}
It will be seen in this article that the famous director Robert Wilson 's Einstein on the Beach production goes through the post dramatic filter of the Train scene by going deep into the post dramatic. The images, dancers, light and music of the scene, which will be examined through the breaking of the dramatic through the post dramatic elements, will also be examined. For this, it is necessary to first know the dramatic theater elements, then analyze how these elements are broken in the Postdramatic. Because in postdramatic theater, we see what the dramatic theater is rather than what it is. As Lehmann conveyed, we cannot describe the term postdramatic with the term "post-dramatic". We can describe the dramatic with perhaps imaginative or performative turn. We will see our efforts to find a solution to this problem through the relevant article. The corresponding production is a long opera that is not the subject of Einstein's emerging from a famous beach photo. Some important details, from Einstein's appearance to some of his theories, have been turned into a stage-by-show visual show. Summary information of the enrichment of the images, which is one of the most basic outcomes of post dramatic and the most known technique of Robert Wilson, with the performances of the dancers on the stage, the breaking of the game text, as well as bringing the audience to an illusion in a different dimension, will be explained under a single title.
\end{abstract}

\section{To cite this article}

Turan, S. (2020). Postdramatic review of the Einstein on the Beach/Train scene by Robert Wilson. Journal for the Interdisciplinary Art and Education, 1(1), 21-28. DOI: http://dx.doi.org/10.29228/jiae.2

\section{Introduction}

'Post' here is to be understood neither as an epochal category, nor simply as a chronological 'after' drama, a 'forgetting' of the dramatic 'past', but rather as a rupture and a beyond that continue to entertain relationships with drama and are in many ways an analysis and 'anamnesis' of drama." (Barnett, 2008).

In order to distinguish the dramatic from the post dramatic, the dramatic must be analyzed well. Because without assimilating the essential and formal elements of the text that are essential in the dramatic, for example, in the post dramatic, not after the dramatic, we may not understand the reason for the breaking of the text. Moreover, we may not be able to speak of a post-dramatic performance without ignoring the natural representation in a dramatic text as well as the powerful task of the plot. Therefore, the dramatic emphasis in the unity of event, time and space is far from meaning in post dramatic! we may not be able to question the difference when we witness how it was destroyed by a regime. If we quote from a magazine article written that the famous philologist Péter Szondi focused on Modern Drama Theory;

"...The Modern Drama, where he first established the idea that dramatic form is not an abtract entity, independent of time and place, but rather inextricably tied up with the content it informs..." (Hays, 1983).

At this point, we need to mention the revised version of the dramatic, not the post-dramatic, the "postdramatic theater" of Hans-Thies Lehmann, as well as the text-performance idea through an unpublished article in academic language and by Robert Wilson's Einstein-made example. 
'Lehmann's book in many ways seems a continuation of Szondi's project, but continuation that is at the same time based on a major revision and reassessment of Szondi's predominantly Hegelian model. Postdratisches Theater, if compared to Szondi's essay, is also indicative of the major paradigm shift that has occurred in theatre studies since the 1960s, mostly as a result of changed theatre practices, but also of the increasing impact of performance studies on theatre scholarship. Lehmann regards performativity, not rootedne ss in dramatic text, as the major constituent of theatre. The notion of "postdramatic" however, does not imply that theatre no longer uses texts, or that writing plays would no longer be possible (or relevant), it only that the other components of the mise en scene are no longer subservient to text." (Wessendorf, 2003).

However, the distance from the meaning in the postdramatic and / or contrasting text / performance is not a long distance between the audience and the theater. Perhaps the audience will, after a post dramatic staging, will establish a connection between an event he experienced one day and the post-dramatic production he is watching at that moment, maybe it will make sense.

In the post dramatic one always breaks an element. This element does not have to be the text of the game. Because we can put any dramatic text on the stage in a dramatic way. However, we cannot think of the opposite. Because some or all of the elements that are dramatic in post dramatic can break. For example, the break in dramatic text in post dramatic reveals a different theatrical performance presentation beyond auditory, visual and time space. We call this text, for example, the landscape text in Robert Wilson's Theater of Images together with Gertrude Stein. All the elements in the stage, like a landscape, are intertwined and form the meaning. But in many productions without space, which can be beyond time or reality, the audience will realize that they do not understand anything from the so-called text. Or the audience who has read a dramatic text before and came to the post dramatic show will be able to argue that the text after the production has been broken too much and there is no meaningfulness in the scene. However, one of the most basic elements we should know about post dramatic is;

"In postdramatic theater, stage text and written text differ from each other, and the staging itself is shaped like a text." (Aksoy, 2012).

In this article, the "Train" scene from the production of Einstein on the Beach by Robert Wilson will be examined through the post dramatic elements. Each review phase will examine how Einstein was given a post-dramatic meaning to the scene, inspired by any beach photograph.

The opera Einstein on the Beach premiered on July 25, 1976, under the direction of Robert Wilson and also organized by Wilson and the famous composer Philip Glass, at the Avignon Festival in France. Later, he performed at the Princeton McCarter Theater in New York in 1984, then in New Jersey in 1992, and finally at the Berlioz Opera in France again in 2012. The production consists of 4 parts and at the end of each part, the breaks called Knee Play are placed. The four sections are outlined; It shows distribution as "Train", "Trial", "Space", "Spaceship". After the first knee play, the "train" stage, which will last about 25 minutes, is passed. The train scene will be examined in detail along with the postdramatic theater throughout the article with the idea that the scene is the most intense and meaningful as personal interpretation. Then the stage of "Hearing" is started. In the trial stage, we see Einstein for the first time. He has a violin in his hand. Other fixed / silent players accompanying Einstein are the two remaining players from the first knee play. The stage is represented by judges and other actors by name. Another important element of this scene is the text, which we can consider as a dramatic element, takes place for the first time with a verbal activity. However, when the text is carefully listened, it will be noted that poetry and imagination prevail in the text. Antonin Artaud's idea that we can interpret it as "the transition from the author's text to the production text" and the directive side of the performative and / or poetic as a requirement of Robert Wilson's Theater of Images, thus a new language is encountered. "What Artaud said was to go beyond the verbal side of the language and to distribute the role of the God-author between the director and those on stage. So it would be necessary to look for a new language and stage graphic on the stage." (Demirkol, 2013). As the related texts are written in poetry and imagery, the audience is exposed to images in accordance with Wilson's Theater of Images. And, as in the postdramatic theater, it has become the audience's task to make sense of production. 


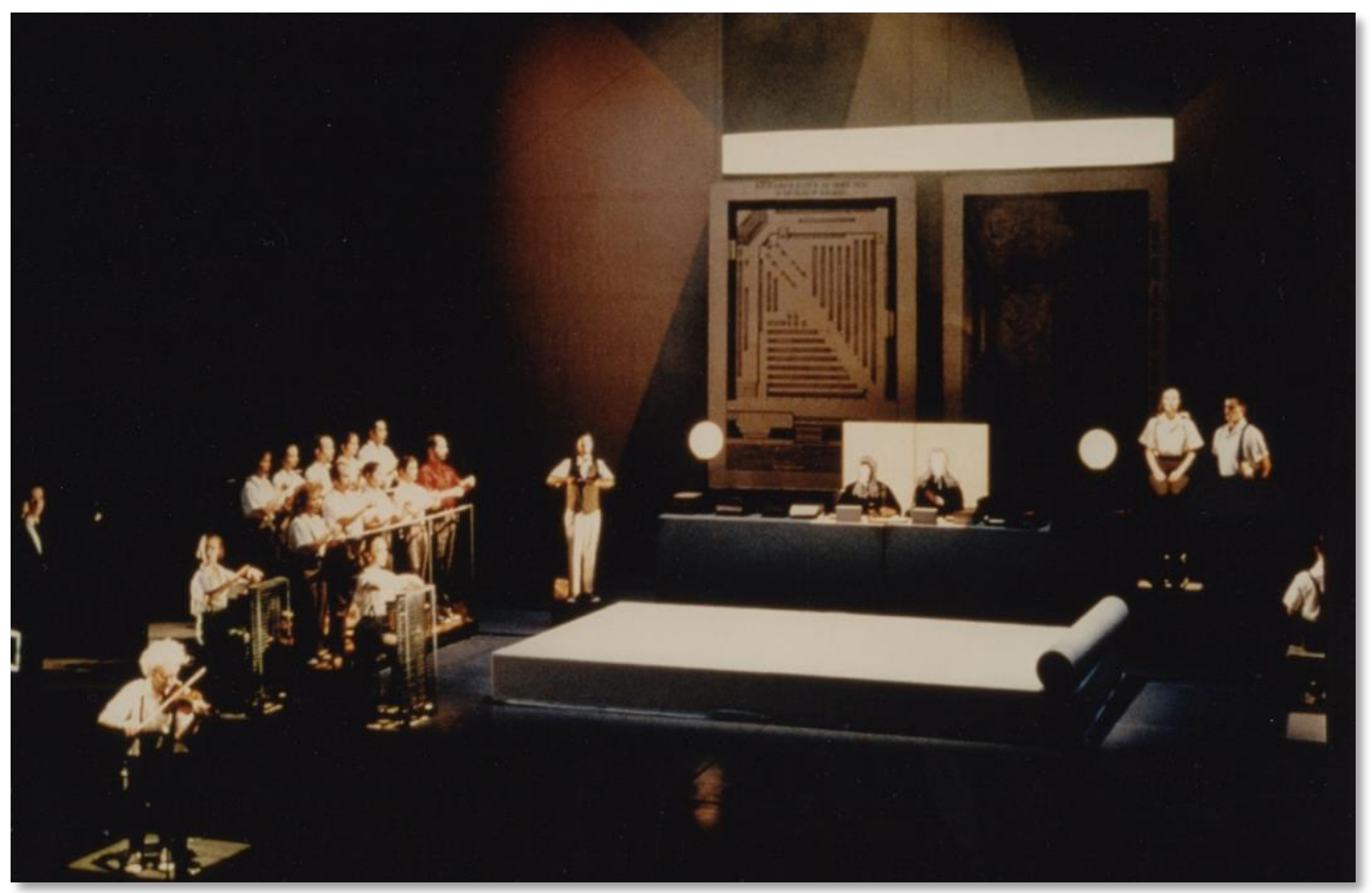

Figure 1.

Einstein On The Beach (1976) / Trial (Bed) Episode (http://www.robertwilson.com/einstein-on-the-beach )

After the trial stage, there is a section called "Space" containing the space ship scene. In this section, a regime draft in which the performance gains weight in the postdramatic is seen. Einstein dances eight dancers led by choreographer Lucinda Chils! We are watching with. In this episode, where music, text, light and choreography gain weight, Einstein is observed by the audience.

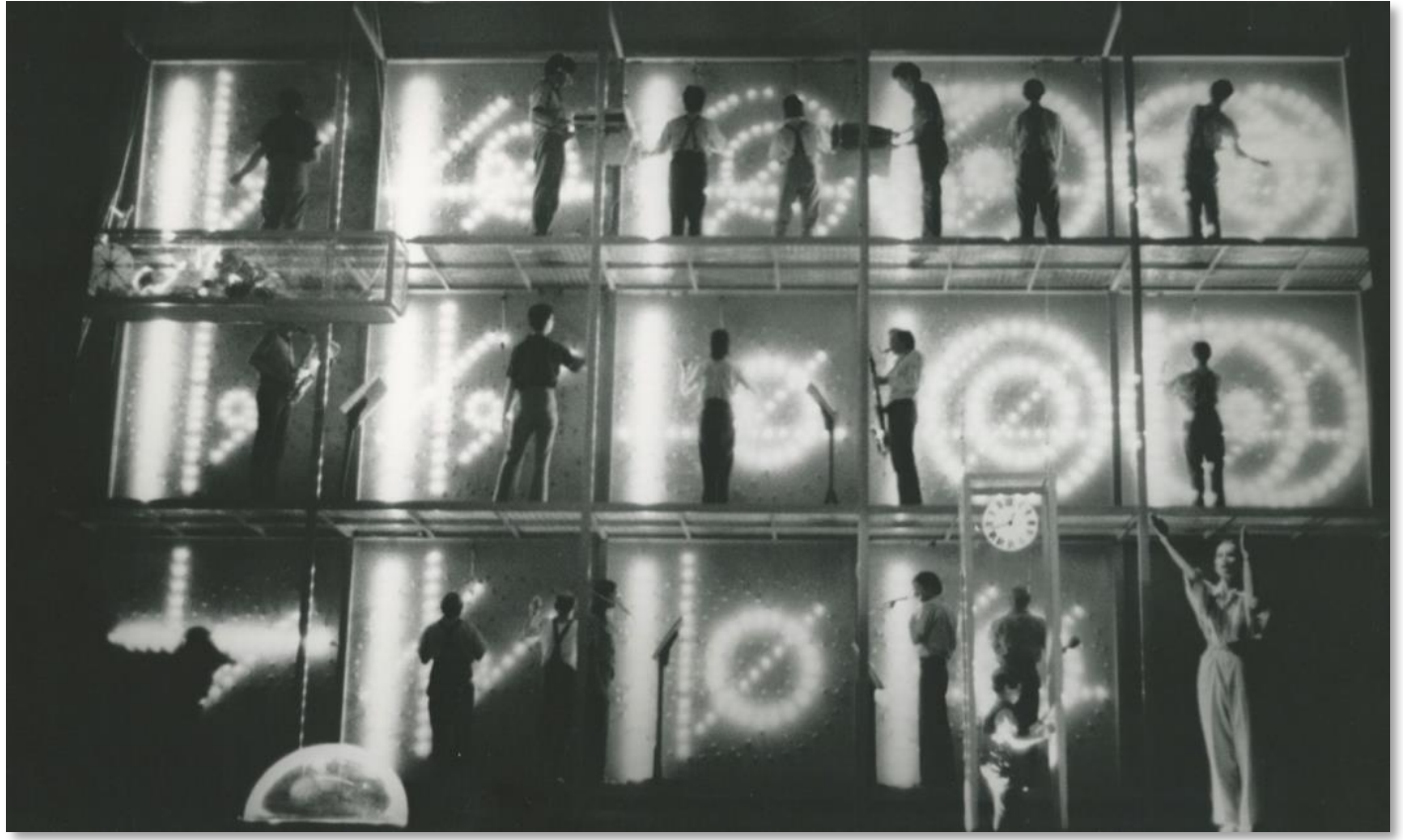

\section{Figure 2.}

Einstein On The Beach (1976) / Field (Space Machine) Episode (http://www.robertwilson.com/einstein-on-thebeach )

It is also worth mentioning the director of the production, Robert Wilson. With the development of new currents, new vocabulary technique and decor / music / performance understanding in the theater, we all see that changes are made in stage, regie and writing techniques in general. The plot in the theater is no longer in a hierarchical order. The characters are not depicted in detail. Even though it is not at the time of watching in the theater, the power of reminding the presentation was developed with the many events to be experienced subconsciously or after the 
presentation. From time to time on the stage, the rain of images, which is a world of images, brings a perception beyond the time and space to the audience, and the perception form of the performative is revealed from time to time. The performative is again the human body. However, this body serves image and music rather than serving the stage, and sometimes the body and its limbs become the basis of the text (if any).

"Bodies and people appear as impenetrable (sacred) objects, rather than as tools of ordinary trickery used to reflect certain pre-determined energies and meanings of the plays.." (Carlson, 2013, p.168) .

And in the mentioned theater there is mostly no text and it is not concrete. While all this is counted, one of the first names that come to mind is Robert Wilson. Wilson's theater is different from image and sound. These elements, which are in parallel with each other, are separate from each other when detailed. The purpose here is clear;

"Wilson's intention is for the sound and the image to function as two separate units within the theatrical environment..." (CardwellRambo, 2013).

Because Wilson's productions have otherness from the text. The viewer watches the visual, experiences and tries to interpret it rather than an incident. Looking at the result, there is a high probability that countless audience comments have been obtained. This shows how diverse and versatile Wilson's theater is. In this theater, it may not be explained how the tree blooms or how the paint came. Although it is said, it may not be understood. Instead, worldly actions around the tree, namely images and bodies, are presented (not described, there is no narrative.)

"By structuring his productions around visual images rather than a written text, he significantly downplays the narrative aspect of theatre to provide a truly visionary experience. Characterized by fragmentation and juxtaposition of visual and aural elements, Wilson's theatre is more corcerned with form and structure than it is with plot or linear narrative" (Wilcox, 1994).

When you look at the shape and structure, we also see that many things are in opposition in space. If we say that the visual festivity, perhaps, consists of these contrasts, we are not considered to be very wrong. It reflects the contrast from every element of the stage, Wilson's theater.

"Vertical/ horizontal, voice/silence, light/dark, fast/slow, cold light/warm light, minimalism/maximalism, realism/abstraction, rational/irrational, comedy/tragedy, the Almighty/grotesque..”(Korad Birkiye, 2007, p.228).

If we leave space and come to the light of space, we will come to the most important stage of Wilson theater. Because technical equipment, especially light, is the most visual power factor in this theater. We can understand how important the technique and especially the light order is for the visual presentation of all body and images by watching any production of Wilson.

Robert Wilson's place in the postdramatic theater will be explored on the Train scene of Einstein on the Beach, for its exemplary and imaginative density, with specific titles and some personal paintings.

\section{"Einstein on the Beach / Train" Stage With Postdramatic Logic The Place Of Images In Postdramatic}

"Dealing with images we should not try to understand the meaning of each image, to apprehend its precise meaning, but to feel those images, to let our memories and imaginations wander: the meaning of an image is the image itself. Image is a language. All images also are surfaces and, as such, they reflect what is projected on it." (Boal, 2005).

Post dramatic theater has brought a new stage aesthetics to the art of drama. In this aesthetic, there may be a heap of indicators (rain of images) or a shortage of indicators in parallel with the logic of Peter Brook. One of the most important elements in post dramatic is Image. As the reason for this; In postdramatic theater, images and theater have come to the fore, mostly as we get from the famous director Robert Wilson, with the breaking of the influence of the play text and speeches. And this, as I mentioned in the previous section, completely broke the dramatic one.

"The absence of dialogue leads to the predominance of the stage picture in the Theatre of Images. This voids all considerations of theatre as it is conventionally understood in terms of plot, character, setting, language and movement. Actors do not create "roles". They function instead as media through which the play-wright expresses his ideas; they serve as icons and images. Te.xt is merely a pretext a scenario" (Marranca, 1976).

Images can indicate the purpose of the director's and author's departure with his presence or absence. It can even reveal the entire map. Post a dramatic writer and director can interpret each image in a production that has image intensity in a way that makes the audience confused. Or it can target the same thing with image poverty. Because 
image means breaking reality on stage; Because the image means that the viewer passes from one abstract situation to another without performing interpretation and therefore confusion.

"Indicators vary with their extremely incomplete or highly intensive usage. According to the usage of time and space, the audience either fills in the meaning gaps himself or extracts meaning from extended used indicators" (Abal1, 2005).

\section{Postdramatic Filter of the "Train "Stage}

When we examine the Train section of Einstein on the Beach, in addition to the image rain of Robert Wilson, for example, the song given during the dances of the dancers is not read on the lips of the dancers. Names, voices that can be read on the lips are given from the sound columns. This shows us Wilson's desire to present a new reality against reality on the stage, a new reality that breaks reality. This illusion that we are not accustomed to breaks the reality of the dramatic, as the audience is confused. However, we need to be sure that; this confusion will find meaning somewhere in everyday life.

As is known, there is a hierarchical order on the stage. The event begins, develops and ends. However, post does not have to be dramatically; The hierarchical order can be disrupted.

"When the final chapter in great tragedies is always known, readers and audience begin to question events to learn how the story progresses and ends in postdramatic tragedy. No longer dramatic texts and non-bierarchical structure have become a rule in postdramatic tragedy.” (Günenç, 2019).

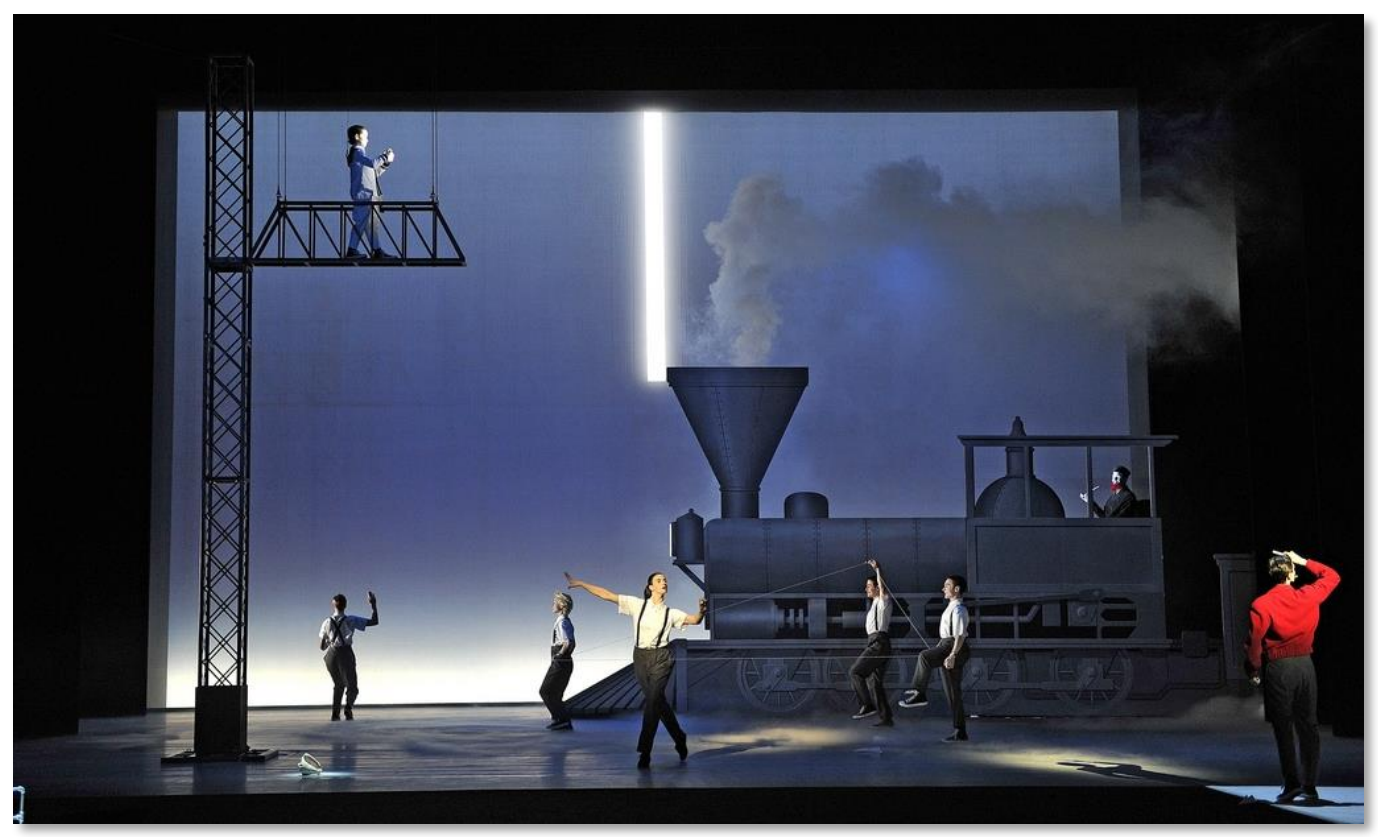

\section{Figure 3.}

Einstein On The Beach (2012) / Train Episode (http://www.robertwilson.com/einstein-on-the-beach)

In the Train scene of Einstein on the Beach; A child carries a light box in his hand. The image, which we call the light box, is perhaps the representative of a moon or star. This goes into personal interpretation in postdramatic. A teenager in a red jacket, simultaneously with the child, shows his actions to the audience on his own plane. There is also a Machinist who brought the Train to the stage. The machinist continues his journey with his pipe. In the train section, there are characters and actions that develop as a whole but within a fragmented structure when it spreads to the general. And every character and action actually breaks the hierarchy of dramatic elements like light, music. Moreover, the dances of the characters in which Einstein's costumes on the stage are imagined break their dramatic hierarchy on the stage.

"However, here it is a whole consisting of steps, incomprehensible gestures, and original choreographic arrangements that have not traditionally conformed to the styles that determine dance. This dance not only avoids the coding of the known dance, but also builds a unique aesthetic." (Ünal, 2004).

The body is also a powerful indicator in the postdramatic theater as much as decor, language and light. And this indicator, as previously discussed, should be purified from the hierarchical structure. Each individual's body must find its meaning in its own space, that is, the individual must also be liberated from the body. 
"In order truly to approach the postdramatic, Lehman makes clear, the brdy must be freed from the constraints of the mimetic character, traditionally derived from the dramatic text, and set free to register as purely performative." (Carlson, 2015).

When we look at the production of Einstein on the Beach, every body has a representation and a certain space on the stage. Although the dancers seem disconnected from each other, a connection can be established between their actions after a while. This bond is actually fed by the opposition of movement and immobility of the actor and the inactive player or a single player. Robert Wilson, “... movement and stillness; utilising these two contrasting concepts emphasizes the disconnection of the body and its limbs from each other" (Doğrusoy, 2019). In the Train section, the actress in the red shirt is slow on the stage and despite her fast action by her co-stars, she has taken place on the stage with slow motion, fast movement (jumping) and neutral movements throughout the episode.

\section{Testing Dramatic Text that has been Fractured with the Postdramatic}

"the text ... is considered only as one element, one layer, or as a 'material' of the scenic creation, not as its master."

(Lehmann, 2006)

It should be emphasized again that the images (indicators) and / or action have the power to dramatically break the text. In a mostly dramatic text, the time and place of each image or action was calculated.

"A dramatic script is a tgeatre universe in its text form, a literary structure based on several dramaturgy principles: the separation of roles, dialogues, dramatic tension, character action, space/ time directions." (Rădulescu, 2019).

However, in a post-dramatic production, images and actions do not have to have a simultaneous and accompanying order. The text may of course be, but it does not have to be at the core of the production, similar to what Lehmann conveyed. In postdramatic theater, mostly performance (action) and indicators, and sometimes words (not necessarily dialogue) are dominant. We can give examples to the indicators from the Train scene; A chair, a seashell, a 19th century steam train, a paper airplane, a light box, a pipe, a wand in the hands of a few players, a newspaper, a light that divides the background in the scene in the train scene.

In dramatic texts there are before and after the event, place or time. But it doesn't always have to be like this in post dramatic. Time and action can lose their dramatic feature through many repetitions, that is, a dramatic break can occur. As an example of repetitions; A long-haired female dancer repeating the same round-trip movement more than 100 times throughout the episode, unlike the actor, with extremely slow movements, an action like jumping in places, repeatedly repeats the same movement ... demonstrates the dramatic break in the stage. When the viewer adapts to these repetitions, he has a partial illusion. It begins to play a role away from text and theme, close to the meaning and timing of the game.

"The audience becomes distracted from the main plot and focuses on the act of repetition and its tiny changes, a situation that leads to a turn of importance from the meaning of the play to its structure, but also to the concept pf time and its relevance" (Gemtou, 2014).

\section{Einstein in Postdramatic}

When we examine Wilson's regime in detail, we can see Einstein's Theory of Relativity on stage. The elements that show us this theory on stage are; time, images, use of light, space, energy, speed and movements. Movement and energy in accordance with space, which gains activity with light and music from these elements, actually proves Einstein's theory. In accordance with the theory, in the Train scene, in addition to the simultaneous movement of the relevant elements, a light line appears in the background each time (the light is seen 3 times throughout the scene). Each character and image on the stage is that the light divides the scene in two while it is positioned independently of each other, although the time and space flow in the same way for everyone, although it is perceived differently. In order for a region with the same space to be clearly perceived, the creation of space and time, that is, during the four dimensions, everyone started to gradually create their place on the stage. When we come to the final of the train scene, everyone has taken its place now, so according to the theory, the width, length and depth of the stage have become perceptible, that is, it has also been provided with three dimensions. At this stage, the platform on which the child is located begins to bend towards the train space. Wilson's aim at this point is to present Einstein's Theory of Relativity. "According to the General Theory of Relativity, although the objects are always on the straight lines in four-dimensional space-time, in three-dimensional space, they seem to us as if they were drawing curves." (Hawking, 1988). In this way, it is explained in the stage finale of the platform that most of them are bent over. And one conclusion we made is that; light, motion and energy, 
which are among the benefits of space, fulfilled Wilson's Theory of Relativity. In addition, Wilson achieves another goal; "Wilson explains that while designing the play, he wants to bring Einstein's both scientist and fantastic attitude in together" (Demirkol, 2013). Einstein's dreamy attitude, on the other hand, could be reflected by the images created on stage and the presence of light / music shows.

Postdramatic Analysis of the Train Scene in the Context of Causality

In addition to the interpretation of the Train scene, which was detailed in the previous sections, in the light of the Postdramatic Theater, two summary tables will be given;

Table 1.

Dramatic and Postdramatic Theater Comparison

Some Indicators of Dramatic

Postdramatic Power

Hierarchical Order

Simultaneously; but a string of independent actions. Dramatic text is

Music / Sound Effects broken. (The text is not sacred). The performance text is dominant.

Music / Sound Effects

Those belonging to the stage: Space - light, those belonging to the Player (Dancer): Speed-motion, Both space and the player: Energy

Facial Expression / Gesture

During the Light, Energy-Speed-Movement + Demonstration, there is no "character", it is focused on physicality and body. All gestures are prepared accordingly.

\section{Spatial Positioning of Place}

Each player (dancer) has its own position. Each location is elongated, independent of other players. Therefore, independent Energy-Speed Motion and a mystical space

Decor Imaginary Density (Whole in itself)

In addition to the table; some of Einstein's information can be observed in a post dramatic interpretation of Einstein's Robert Wilson filter on the train scene.

Table 2.

Einstein's Images and Submissions / Cause-Result Relationship

\begin{tabular}{lll}
\hline Physical appearance & Einstein's reminder & $\begin{array}{l}\text { Dancers' use of white shirts, black trousers } \\
\text { and suspenders }\end{array}$ \\
\hline Beach Pho & Reminding the photo & Sea shell \\
\hline The theory of relativity & Reminding the theory by R. Wilson & $\begin{array}{l}\text { (Everyone's common relative) The light line } \\
\text { in the background, (Every dancer takes her } \\
\text { place in space) Gaining 4 dimensions, } \\
\text { (gaining width, longitude and depth), } \\
\text { gaining } 3 \text { dimensions, tilting the platform on } \\
\text { which the child is. }\end{array}$ \\
\hline
\end{tabular}

\section{Conclusion}

In the Train scene of Einstein On The Beach, we observe that the dramatic one is very much broken. Evidence of this can be given as evidence of breaking the sanctity of the text, breaking the time-space unity on the basis of action and action, without a dramatic hierarchy. In the post dramatic theater, we can not see anything like the dramatic, and now it is much more difficult to analyze the image, the event and the character in the post dramatic as the audience. In post dramatic, which makes an intellectual process compulsory, there is a theater experience that suggests the issue raised by the production and the results of the causal link between each element and person. The production was set out from a famous beach photograph of Einstein. And in this world of images, Einstein's life and theories are also exposed. Thanks to this production, we can observe the fact that a light that is thought to be simple creates projections with many joints. In addition, we can see much more than a classical text, what performance can tell rather than words, what is told is not actually meant to explain, what signs and elements are broken in the theater we memorize in post dramatic productions. (The relevant indicators and elements are explained in detail in the article.) And I suggest going to one post dramatic production to stop how these breaks affect us as the audience. You will see how each known 
becomes unknown with another unknown and how we have been forced into an intellectual process in this unknown, and we are constantly left on stage.

\section{Biodata of the Author(s)}

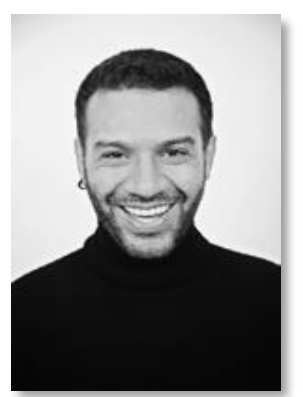

Şahin Turan holds a master's degree with thesis in Theater Direction. Apart from directing, he received training on dramatic playwriting. He is one of the directors of the project called

Balat Monologists Museum. He is also one of the academic writers in the Theater Magazine.

E-mail: sahin.turan85@outlook.com Phone: +905325230055 ORCID No: 0000-0003$1155-8088$

\section{References}

Abalı, G. (2005). Murathan Mungan Oyunlarnda Postdramatik Ögeler. Master Thesis. Istanbul University, Istanbul, Turkey. Aksoy, N. (2012). Peyzaj Metin Kavramı ve Sahneleme Anlayışı. SDUArt-e Journal, 135.

Barnett, D. (2008, Jan 30). When is a Play not a Drama? Two Examples of Postdramatic Theatre Texts. (C. U. Press, Productor) Cambridge:https://www.cambridge.org/core/services/aop-cambridgecore/content/view/FFC43A35F2A017C40CEA94DF3BE15EA4/S0266464X0800002Xa.pdf/when_is_a_play_not_a_dra ma_two_examples_of_postdramatic_theatre_texts.pdf

Boal, A. (2005). Games For Actors And Non-Actors. (A. Jackson, Trans.) Londra: Taylor and Francis e-Library.

Cardwell-Rambo, M. (2013). Wilson and musical collaboration: the dramaturgy of music and musicians in Robert Wilson's practice. (Master of Literature Thesis). University of Glasgow, UK.

Carlson,M.(2013). Performans Eleștirel Bir Giriş. Ankara: Dost Kitapevi Yayınları.

Carlson, M. (2015, Sept./Dec.). Postdramatic Theatre and Postdramatic Performance. https://www.scielo.br/pdf/rbep/v5n3/2237-2660-rbep-5-03-00577.pdf

Demirkol, Y. (2013). Robert Wilson Oyunlarnda Post Dramatik. Anlatı Teknikleri, Master Thesis, Istanbul University, Istanbul, Turkey.

Doğrusoy, G. (2019). Tiyatroda Teknoloji Kullanım ve Robert Wilson Rejilerinde Teknoloji. Master Thesis. Istanbul Aydın University, Istanbul.

Gemtou, E. (2014, September 20). Exploring the Possibilities of Postdramatic Theater as Educational Means. International Journal of Education o the Arts, 15(12), 7.

Günenç, M. (2019, August 1). A Pradigm of Dramatic and Postdramatic Tragedy:Simon Stephens's Motortown. Folklor/Edebiyat, 25(99), 641.

Hawking, S. (1988). Zamanın Kısa Tarihi, (Çev. Murat Uraz, Sabit Say). İstanbul

Hays, M. (1983). Drama and Dramatic Theory: Peter Szondi and the Modern Theater. Boundary 2 (Peter Szondi'nin Eleştirisi adlı Yayin), 11(3), 69-70.

Korad Birkiye,S.(2007).Çăgdaş Tiyatroda Kültürlerarası Eüilim. Ankara: DE Kİ Basım Yayım.

Lehmann, H.-T. (2006). Postdramatic Theatre. (K. Jürs-Munby, Trans.) UK: Taylor \& Francis e-Library.

Marranca, B. (1976). The Theatre Of Images. https://static1.squarespace.com/static/5436a202e4b09dbd92ec6032/t/55eb29f6e4b08b68bec10d5a/1441475062093/Prefa ce+to+Theatre+ of+Images.pdf

Rădulescu, C. (2019, June). From Dramatic Text to Visual Dramaturgy. https://www.researchgate.net/publication/333753503_From_Dramatic_Text_to_Visual_Dramaturgy

Ünal, H.A. (2004). Yirminci Yü̈ynl Sonunda Tiyatroda Arayıslar: Postmodern Tiyatro, Doctoral Thesis. Istanbul University.

Wessendorf, M. (2003). The Postdramatic Theatre of Richard Maxwell. Mānoa, Hawai, Amerika.

Wilcox,D.R.(1994). The Language of Visual Theatre: Sign and Context in Josef Svoboda, Meredith Monk, and Robert Wilson. (Doctor of Philosophy). University of Washington, USA. 